Ambiente \& Água - An Interdisciplinary Journal of Applied Science
ISSN 1980-993X - doi:10.4136/1980-993X
www.ambi-agua.net
E-mail: ambi-agua@agro.unitau.br

\title{
Effects of initiating anaerobic digestion of layer-hen poultry dung at sub-atmospheric pressure
}

\author{
doi: 10.4136/ambi-agua.1238
}

Received: 02 Nov. 2013; Accepted: 12 Dec. 2013

\author{
Chima C. Ngumah"; Jude N. Ogbulie; Justina C. Orji; Ekperechi S. Amadi \\ Federal University of Technology Owerri - Owerri, Imo State. Nigeria \\ Department of Microbiology \\ *Corresponding author: e-mail: ccngumah@yahoo.com, \\ ogbujuan@yahoo.com, chiookolo@yahoo.com, amadies2001@yahoo.com
}

\begin{abstract}
This study investigated the effects of initiating anaerobic digestion (AD) of dry layer-hen poultry dung at the sub-atmospheric pressure of $-30 \mathrm{cmHg}$ on biodegradation, biogasification, and biomethanation. The setup was performed as a batch process at an average ambient temperature of $29 \pm 2{ }^{0} \mathrm{C}$ and a retention time of 15 days. Comparisons were made with two other experiments which were both begun at ambient atmospheric pressure; one was inoculated with digestate from a previous layer-hen dung $\mathrm{AD}$, while the other was not inoculated. The bioreactors initiated at sub-atmospheric pressure, ambient atmospheric pressure without inoculum, and ambient atmospheric pressure with inoculum showed the following for biogas and biomethane yields respectively: $16.8 \mathrm{~cm}^{3} \mathrm{~g}^{-1} \mathrm{VS}$ and $15.46 \mathrm{~cm}^{3} \mathrm{~g}^{1} \mathrm{VS}, 25.10 \mathrm{~cm}^{3} \mathrm{~g}^{-1} \mathrm{VS}$ and $12.85 \mathrm{~cm}^{3} \mathrm{~g}^{-1} \mathrm{VS}, 21.44 \mathrm{~cm}^{3} \mathrm{~g}^{-1} \mathrm{VS}$ and $14.88 \mathrm{~cm}^{3} \mathrm{~g}^{1} \mathrm{VS}$. In the same order, after $\mathrm{AD}$, the following values were recorded for volatile solids and total viable counts (prokaryotes and fungi) in the digestates: $40.33 \%$ and $23.22 \times 10^{6} \mathrm{cfu} \mathrm{mL}^{-1}, 43.42 \%$ and $22.17 \times 10^{6} \mathrm{cfu} \mathrm{mL}^{-1}, 41.11 \%$ and $13.3 \times 10^{6} \mathrm{cfu} \mathrm{mL}^{-1}$. The feedstock showed values of $83.93 \%$ and $3.98 \times 10^{6} \mathrm{cfu} \mathrm{mL}^{-1}$ for volatile solids and total viable count respectively. There was a slight difference in the volatile solids of the digestates of the three bioreactors after AD. The $\mathrm{pH}$ recorded for the feedstock slurry before AD was 7.9 at $30^{\circ} \mathrm{C}$, while after $\mathrm{AD}$, the digestates from all the three bioreactors showed the same $\mathrm{pH}$ of 5.9 at $29{ }^{\circ} \mathrm{C}$. Statistical analysis using ANOVA showed no significant difference in biogas yields of the feedstock for the three bioreactors (A, B, C). ANOVA showed no significant difference for biomethane yields in the bioreactors initiated at sub-atmospheric pressure and for those initiated at ambient atmospheric pressure with inoculums. However, it showed significant difference in the bioreactor initiated at sub-atmospheric pressure and that initiated at ambient atmospheric pressure without inoculums, and significant difference in the two sets of bioreactors initiated at ambient atmospheric pressure (with and without inoculum). Initiating $\mathrm{AD}$ at reduced atmospheric pressure $(-30 \mathrm{cmHg})$ and the addition of inoculum at ambient atmospheric pressure both increased biomethanation, by $20.31 \%$ and $15.80 \%$ respectively. The $\mathrm{AD}$ initiated at sub-atmospheric pressure yielded the least amount of carbon dioxide (a greenhouse gas), and improved biodegradation and biomethanation. The results also suggest that biomethane production is dependent on specific methanogenic growth. Analyzing the populations of methanogens isolated from the different bioreactors in relation to their biomethane yields suggests that Methanosarcina barkeri may have been largely responsible for the differences in biomethane yields.
\end{abstract}

Keywords: alternative energy, biofuel, waste management. 


\section{Efeitos do início da digestão anaeróbica da camada de esterco de aves à pressão sub-atmosférica}

\section{RESUMO}

Os efeitos do início da digestão anaeróbica (DA) da camada de estrume seco de galinha à pressão sub-atmosférica de $-30 \mathrm{cmHg}$ na biodegradação, biogaseificação, e biometanização foram investigados. Foi realizado um processo em lote a uma temperatura ambiente média de $29 \pm 2{ }^{\circ} \mathrm{C}$ e um tempo de retenção de 15 dias. As comparações foram feitas com duas outras experiências; ambas foram iniciadas à pressão atmosférica ambiente, enquanto que uma foi previamente inoculada com digestores de uma camada de estrume de galinha $\mathrm{AD}$, a outra sem inoculação. Os biorreatores foram iniciados à pressão sub-atmosférica, à pressão atmosférica ambiente sem inóculo, e à pressão atmosférica ambiente com inóculo e foram registradas as seguintes produções do biogás e do biometano, respectivamente: $16.8 \mathrm{~cm}^{3} \mathrm{~g}^{-1} \mathrm{VS}$ e $15.46 \mathrm{~cm}^{3} \mathrm{~g}^{-1} \mathrm{VS}, 25.10 \mathrm{~cm}^{3} \mathrm{~g}^{-1} \mathrm{VS}$ e $12.85 \mathrm{~cm}^{3} \mathrm{~g}^{-1} \mathrm{VS}, 21.44 \mathrm{~cm}^{3} \mathrm{~g}^{-1} \mathrm{VS}$ e $14.88 \mathrm{~cm}^{3} \mathrm{~g}^{-1} \mathrm{VS}$. $\mathrm{Na}$ mesma ordem, depois do DA, no produto resultante da digestão foi registrado o seguinte para sólidos voláteis e contagem total de viáveis (procariotas e fungos): $40.33 \% \mathrm{e}$ $23.22 \times 10^{6} \mathrm{cfu} \mathrm{mL} \mathrm{m}^{-1}, 43.42 \%$ e $22.17 \times 10^{6} \mathrm{cfu} \mathrm{mL}^{-1}, 41.11 \%$ e $13.3 \times 10^{6} \mathrm{cfu} \mathrm{mL}^{-1}$. Na matéria-prima foram registrados $83.93 \%$ e $3.98 \times 10^{6} \mathrm{cfu} \mathrm{mL}^{-1}$ para sólidos voláteis e contagem viável total, respectivamente. Houve pequena diferença nos sólidos voláteis no material digerido dos três reatores após a DA. $\mathrm{O}$ pH registrado para a pasta de matéria-prima antes do DA foi de 7,9 a $30^{\circ} \mathrm{C}$, enquanto que após a DA, os digestores de todos os três reatores registrou o mesmo $\mathrm{pH}$ de 5,9 a $29{ }^{\circ} \mathrm{C}$. A Análise de variância não mostrou diferença significativa na produção de biogás da matéria-prima nos três biorreatores (A, B, C). Para a produção de biometano a ANOVA revelou que não houve diferença significativa nos biorreatores iniciados à pressão sub-atmosférica e aqueles iniciados à pressão atmosférica ambiente com inóculo, porém, houve diferença significativa nos biorreatores iniciados à pressão sub-atmosférica e naqueles iniciados à pressão atmosférica ambiente, sem inoculação, e diferença significativa nos dois conjuntos de biorreatores iniciados à pressão atmosférica ambiente (com e sem inóculo). Iniciando a DA à pressão atmosférica reduzida $(-30 \mathrm{cmHg})$ e a adição de inóculo à pressão atmosférica ambiente, tanto por aumento biometanização $20,31 \%$ e $15,80 \%$, respectivamente. A DA iniciada à pressão sub-atmosférica produziu a menor quantidade de dióxido de carbono (um gás de efeito estufa) e melhorou a biodegradação e biometanização. Os resultados obtidos sugerem que a produção de biometano é dependente de crescimento metanogênico específico. A análise das populações de isolados metanogênicos de diferentes biorreatores em relação às suas produções de biometano sugere que a espécie Methanosarcina barkeri pode ter sido em grande parte responsável pelas diferenças na produção de biometano.

Palavras-chave: energia alternativa, os biocombustíveis, gestão de resíduos.

\section{INTRODUCTION}

Anaerobic digestion (AD) is a widely accepted method of organic waste management due to its high performance in volume reduction, product stabilization, and production of valuable resources (biogas and biofertilizer), which makes the process profitable. Ancient and modern information and practice attest to the fact that $\mathrm{AD}$ is a viable means of treating biomass (Abassi et al., 2012). However, in a highly competitive market, the overall process performance needs to be enhanced in order to optimize both the treatment of waste and the generation of resource products at reduced cost (Vindis et al., 2009). As reported by Delgenes et al. (2003) and Insam et al. (2010), means of optimizing the AD process have been of keen 
interest to many researchers. Palmowski and Muller (2000) described the influence of size reduction of organic waste on digestion efficiency. Ultrasonic treatment has been reported by Tiehm et al. (2001) and Bougrier et al. (2005) to increase digestibility through a size reduction of the organic waste particulate matter. Alkaline pretreatment of spruce and birch to improve bio-ethanol and biogas production was described by Mirahmadi et al. (2010). Muthangya et al. (2009) proposed a two-stage fungal treatment for improved biogas production from sisal leaf decortication residues. Jurcoane et al. (2009) and Pakarinen et al. (2011) in their separate works investigated the effect of enzymatic hydrolysis of feedstock prior to AD on biogas generation and product stabilization. On the other hand, it has been reported that the efficiency of the AD process is also influenced by environmental and operational parameters (treatment), such as: temperature, nutrient availability, light, oxygen levels, $\mathrm{pH}$, presence of inhibitors, and so on (Monnet, 2003). Thus skillfully manipulating these parameters, singularly or in combination, may lead to an improvement in the overall efficiency of the process (Schnurer and Jarvis, 2010). For instance, it has been reported that the regular removal of biogas from a bioreactor, which in turn resets its operation pressure, favors biogas yield. The reasons given were that the removal of produced biogas can increase the attainable microbial population (this can be up to a factor of 12 in the case of extremely thermophilic methanogens), and the removal of gases, for example hydrogen sulfide and ammonia, which may inhibit methanogenesis (Deublein and Steinhauser, 2008).

Jedrzejewska et al. (2006) investigated the effect of maintaining the methane fermentation of blood from slaughter waste at reduced pressure for a 28 day retention period. Their experiments revealed that the bioreactor maintained at sub-atmospheric pressure yielded biogas with higher methane concentrations (by 5.15\%), and a higher and more stable $\mathrm{pH}$ value (7.9 on average) throughout the $\mathrm{AD}$ when compared to the control experiment maintained at ambient atmospheric pressure. In a separate study, Jiang et al. (2010) reported a strong buffering capacity of AD also, but a lower bio-methane production rate of municipal solid waste at lower ambient atmospheric pressure when compared to the control experiment conducted under a higher ambient atmospheric pressure.

Waste management has remained a perennial problem, especially in developing countries where adequate funding, technology, and skill are lacking. A cheap and simple process of gainfully optimizing organic waste treatment would make waste management more feasible (Al Seadi et al., 2008). This study investigates the effect of initiating the AD of dry layer-hen dung at the sub-atmospheric pressure of $-30 \mathrm{cmHg}$ on biodegradation, biogasification, and biomethanation in a 15 day retention time batch process. Its results are compared to the results of two other similar experiments initiated at ambient atmospheric pressure; one was inoculated with digestate from a previous $\mathrm{AD}$, while the other was not inoculated.

\section{MATERIALS AND METHODS}

\subsection{Collection of feedstock}

Dry (air-dried) poultry dung was collected from a household layer-hen battery-cage poultry farm in Owerri (Imo State, Nigeria).

\subsection{Preparation of feedstock slurries}

For each bioreactor, $200 \mathrm{~g}$ of poultry dung (feedstock) was homogenized in $600 \mathrm{~mL}$ of untreated bore-hole water.

\subsection{Experimental set-up}

Three sets of 12 x $20 \mathrm{~cm}$ Equitron stainless steel anaerobic culture jars (Model: 8151) were used as batch reactors. They were labeled 'A', 'B', ' $\mathrm{C}$ ' and each set was replicated three times to give a triplicate sample. The slurries were prepared in $10 \times 11 \mathrm{~cm}$ plastic containers 
and labeled 'A', 'B', 'C' to correspond with the labeling of the bioreactors. About $15 \mathrm{~cm}^{3}$ of inoculum from a previous layer-hen dung AD was added to each plastic container labeled ' $\mathrm{C}$ ' and homogenized. All the plastic containers were covered with perforated lids. The lidded plastic containers were then put into the correspondingly labeled bioreactors. Anaerobiosis was achieved in reactors ' $\mathrm{B}$ ' and ' $\mathrm{C}$ ' using the candle jar method. The bioreactors labeled ' $\mathrm{A}$ ' were depressurized using a vacuum pump to $-30 \mathrm{cmHg}$, which also served the purpose of oxygen removal. All the bioreactors were then placed on a level stable table in a closed room and operated at an average ambient mesophilic temperature of $29 \pm 2^{\circ} \mathrm{C}$ for a hydraulic retention time (HRT) of 15 days. The bioreactors were mixed manually by gently shaking or swirling them once daily.

\subsection{Collection of gas samples}

Gas production was indicated by readings on the pressure gauge of the bioreactor. Gas samples were collected using a modified version of Nda-Umar and Uzowuru (2011). Biogas generation was measured by passing the gas via a tube through a clear solution of filtered saturated calcium chloride solution $\left(2 \mathrm{~g} \mathrm{~L}^{-1}\right)$ in a transparent calibrated vessel. The instant downward displacement of the calcium hydroxide solution was recorded as biogas volume. The biomethane content of biogas was measured by allowing the set-up to stand for 24 hours and the remaining gas volume after the upward replacement of calcium hydroxide solution was recorded as the biomethane volume. The carbon dioxide content was computed as the difference between the biogas and bio-methane volumes.

\subsection{Microbial analysis.}

A tenfold serial dilution of feedstock and the digestate were carried out up to $10^{6}$ tubes in sterile distilled water. Using a sterile syringe, $0.01 \mathrm{ml}$ aliquots (a drop from a $2 \mathrm{ml}$ disposable hypodermic needle) were inoculated on to sterile solidified nutrient agar, sabauraud dextrose agar (SDA), and methanogenic media plates using spread-plate technique for the isolation of bacteria, fungi, and methanogens respectively. The methanogenic media was formulated as described in the Manual of Environmental Microbiology (Stetzenbach, 2002). One set of nutrient agar plates were incubated aerobically and the other anaerobically at $37{ }^{0} \mathrm{C}$ for 24 hours. Similarly, one set of the SDA plates were incubated aerobically and the other anaerobically at ambient room temperature for 3-7 days. The methanogenic media plates were incubated anaerobically at $37^{\circ} \mathrm{C}$ for $7-10$ days. Each set of cultures was done in triplicate with control plates inoculated with $0.01 \mathrm{ml}$ aliquots of untreated bore-hole water. Plates with microbial colonies of 30 - 300 emerging after incubation were counted and their average recorded as colony forming units per millimeter $\left(\mathrm{cfu} \mathrm{mL}^{-1}\right)$ of the sample. The different colonies were repeatedly sub-cultured on fresh media plates in order to obtain pure isolates. Bacteria, yeast, and methanogens isolates were gram stained and subjected to biochemical tests as described by Wistreich (2003). The bacteria and methanogens were identified by comparing their characteristics with those of known taxa using the schemes of Bergey's Manual of Determinative Bacteriology (Hensyl and Folifer, 1994) and The Prokaryotes (2006). Fungi were characterized based on macroscopic, microscopic, and biochemical examinations as described by Domsch et al. (1980).

\subsection{Physicochemical analysis}

Temperature was measured using a mercury thermometer (range, $0-110{ }^{0} \mathrm{C}$ ) and $\mathrm{pH}$ determined with a Hanna Instrument $\mathrm{pH}$ meter (Model: H196107). Total solids (TS) and Volatile solids (VS) of TS were determined using the methods of Pillai (2009).

\subsection{Statistical analysis}

All graphs and ANOVA were generated using Microsoft Excel 2003 software. 


\section{RESULTS AND DISCUSSIONS}

Table 1 shows the cumulative biogas and biomethane yields for all the bioreactors. Though the highest biogas yield was seen in the bioreactor initiated at ambient atmospheric pressure (without inoculum), it also recorded the least biomethane content; while the bioreactor initiated at sub-atmospheric pressure yielded the lowest biogas volume, but had the highest biomethane content. ANOVA revealed that statistically there was no significant difference in biogas yields; however there were significant differences in biomethane yields between the bioreactor initiated at sub-atmospheric pressure and that initiated at ambient atmospheric pressure without inoculum, and between the two bioreactors initiated at ambient atmospheric pressure (with and without inoculum). The average daily biogas yield per gram of feedstock digested obtained here $\left(0.76 \mathrm{~cm}^{3} \mathrm{~g}^{-1}\right)$ at ambient atmospheric pressure (without inoculum) is higher than those obtained by Monnet (2003) $-0.60 \mathrm{~cm}^{3} \mathrm{~g}^{-1}$ and Ojolo et al. $(2007)-0.58 \mathrm{~cm}^{3} \mathrm{~g}^{-1}$.

Table 1. Biogas and biomethane yields.

\begin{tabular}{|c|c|c|c|c|}
\hline \multirow{2}{*}{\multicolumn{2}{|c|}{ Bioreactors }} & \multicolumn{3}{|c|}{ Cumulative yield } \\
\hline & & \multirow{2}{*}{$\begin{array}{l}\begin{array}{l}\text { per gram of } \\
\text { feedstock } \\
\left(\mathbf{c m}^{\mathbf{3}} \mathbf{g}^{-1}\right)\end{array} \\
11.43\end{array}$} & \multirow{2}{*}{$\begin{array}{l}\begin{array}{l}\text { per gram of } \\
\text { total solids } \\
\left(\mathbf{c m}^{\mathbf{3}} \mathbf{g}^{-1} \mathbf{T S}\right)\end{array} \\
13.77\end{array}$} & \multirow{2}{*}{$\begin{array}{l}\begin{array}{l}\text { per gram of } \\
\text { volatile solids } \\
\left(\mathbf{c m}^{\mathbf{3}} \mathbf{g}^{-1} \mathbf{V S}\right)\end{array} \\
16.81\end{array}$} \\
\hline $\begin{array}{l}\text { (A) } \\
\text { Initiated at sub- }\end{array}$ & Biogas & & & \\
\hline $\begin{array}{l}\text { atmospheric pressure } \\
(-30 \mathrm{cmHg})\end{array}$ & Biomethane & 10.51 & 12.66 & 15.46 \\
\hline \multirow{2}{*}{$\begin{array}{l}\quad \quad(\mathrm{B}) \\
\text { Initiated at } \\
\text { atmospheric pressure } \\
\text { without inoculum }\end{array}$} & Biogas & 17.07 & 20.57 & 25.10 \\
\hline & Biomethane & 8.75 & 10.53 & 12.85 \\
\hline \multirow{2}{*}{$\begin{array}{l}\qquad(\mathrm{C}) \\
\text { Initiated at } \\
\text { atmospheric pressure } \\
\text { with inoculum }\end{array}$} & Biogas & 14.58 & 17.57 & 21.44 \\
\hline & Biomethane & 10.13 & 12.19 & 14.88 \\
\hline
\end{tabular}

Figures 1, 2, and 3 show the daily pattern of biogas yields for the different bioreactors their biomethane and carbon dioxide contents. The bioreactor (A) initiated at sub-atmospheric pressure (Figure 1) gives a picture of an AD process with a relatively more evenly distributed gas yield as depicted by gentle slopes in its graphs as opposed to the sharp gradients seen in the graphs of the other two bioreactors, (B) and (C). As biogas yield seems to be evenly distributed within the fifteen-day retention time in bioreactor $\mathrm{A}$, the bulk of biogas yields in bioreactors $\mathrm{B}$ and $\mathrm{C}$ are rather concentrated between days four to nine and one to six respectively. Biogas yield reached its peak on day six in bioreactor $\mathrm{B}$, and on day four in bioreactor $\mathrm{C}$. This supports the well-known concept that inoculating with stock culture prior to fermentation induces a quicker and more stable process (Adelekan, 2012). Results obtained here also show that initiating $\mathrm{AD}$ at sub-atmospheric pressure had the similar effects of increasing biomethanation and thus biodegradation as did maintaining $\mathrm{AD}$ at sub-atmospheric 
pressure throughout the retention period as reported by Jedrzejewska et al. (2006). It should be noted that in the bioreactor (A), initiated at sub-atmospheric pressure, there was an indication of gas yield after the first 24 hours as detected by the pressure gauge, but it was not possible to collect and record gas samples then as the interior pressures of the bioreactors were still below ambient atmospheric pressure.

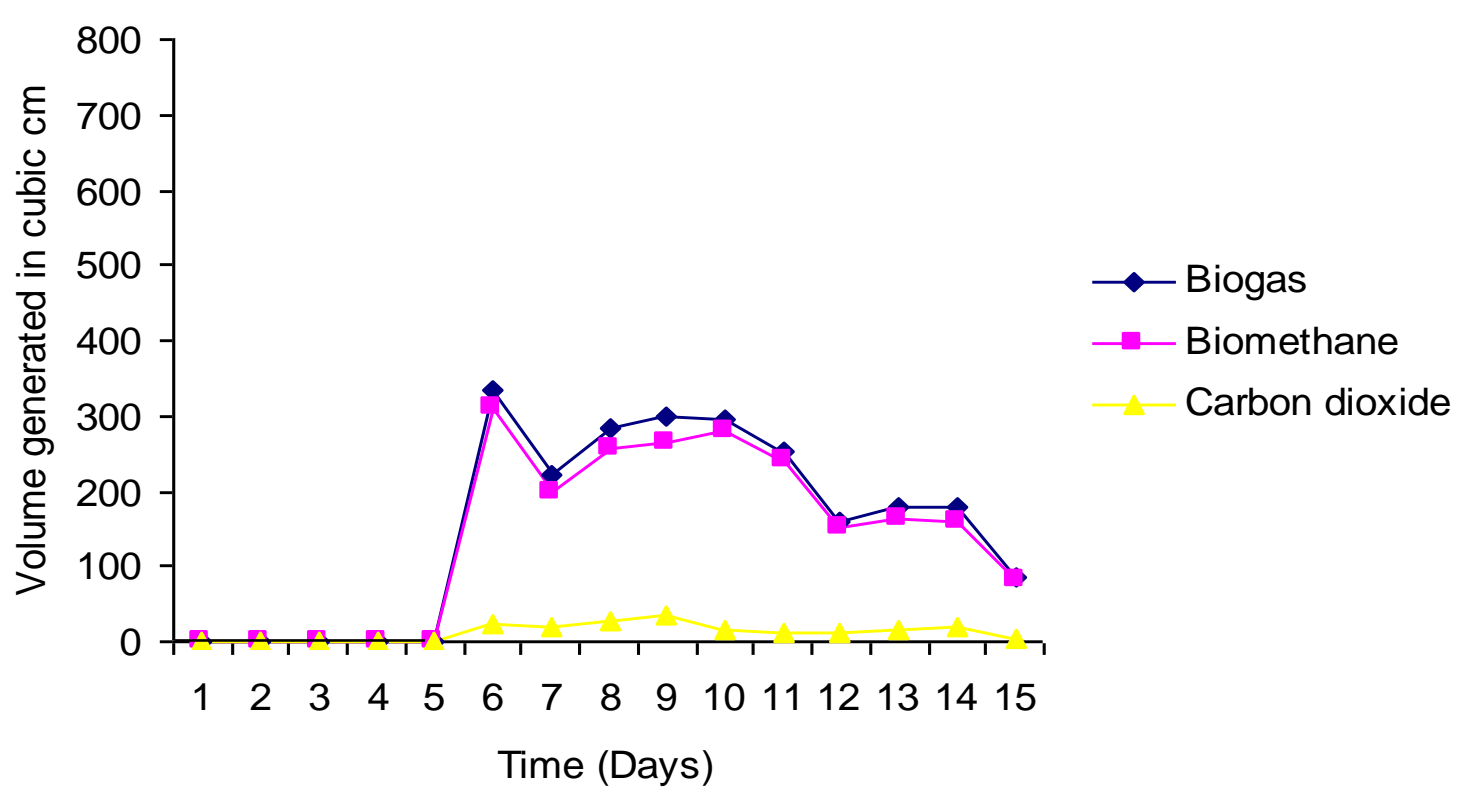

Figure 1. Biogas yield analysis of bioreactor (A) initiated at sub-atmospheric pressure $(.30 \mathrm{cmHg})$.

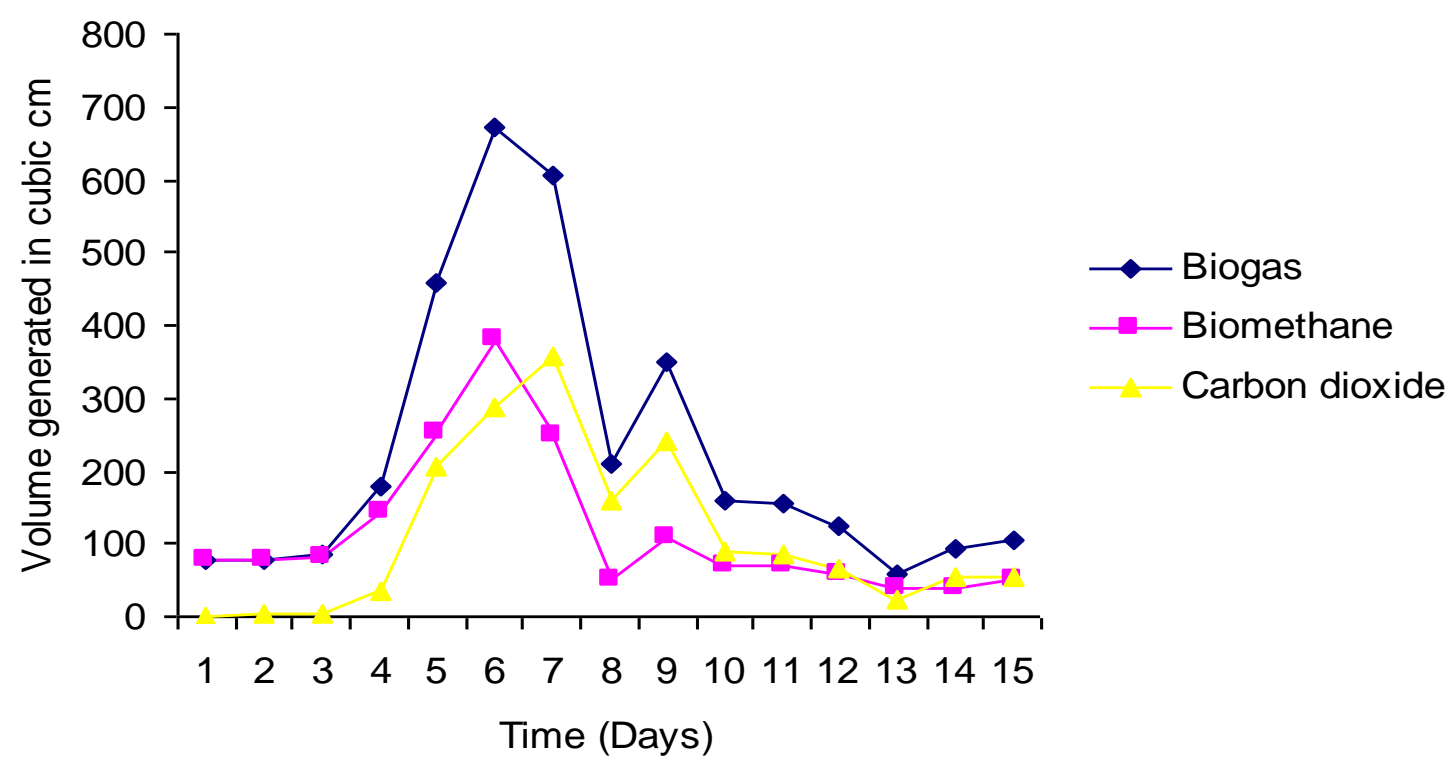

Figure 2. Biogas yield analysis of bioreactor (B) initiated at ambient atmospheric pressure without inoculum. 


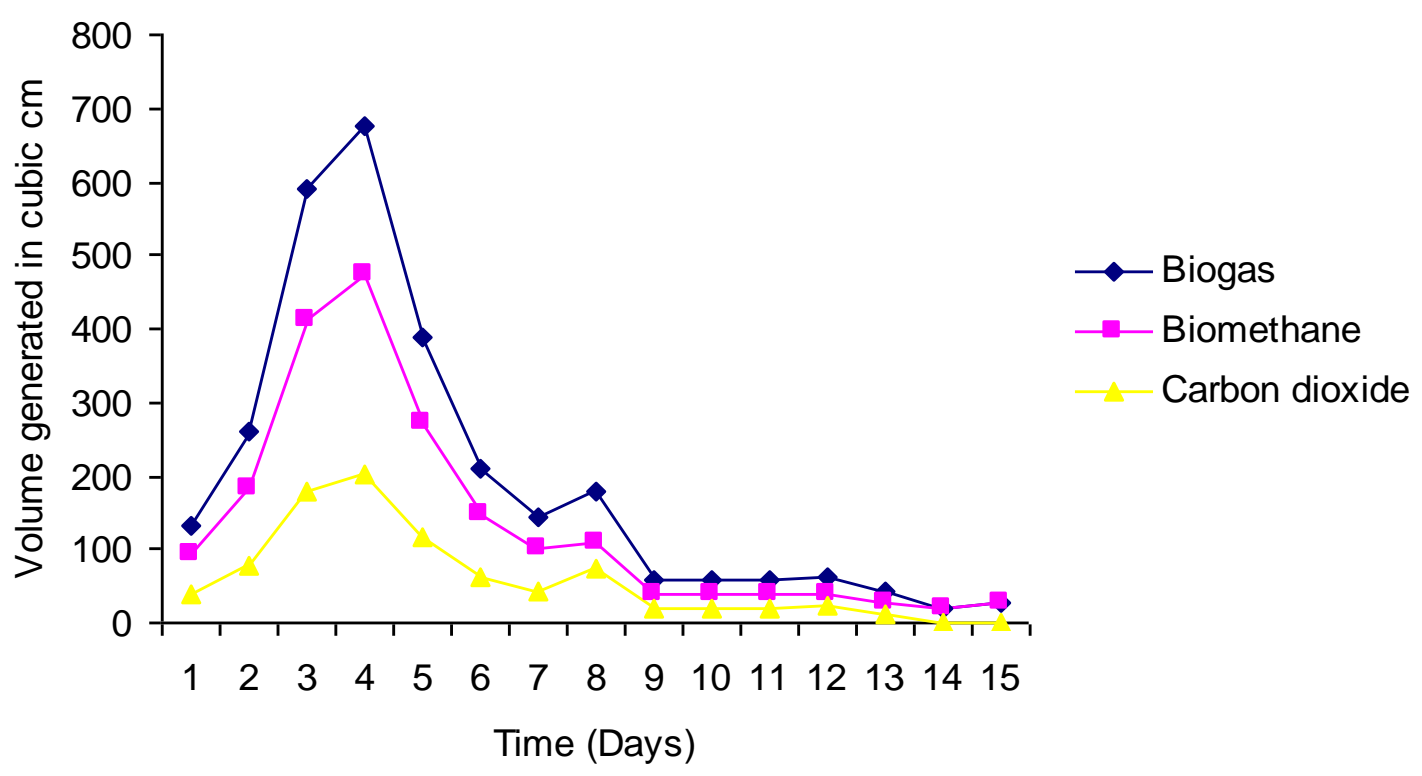

Figure 3. Biogas yield analysis of bioreactor (C) initiated at ambient atmospheric pressure with inoculum.

Table 2 shows the $\mathrm{pH}$ and volatile solids (VS) of total solids (TS) of the feedstock and the digestates from the different bioreactors. From the readings, the different parameters employed (depressurizing at inception for bioreactor $\mathrm{A}$ and the addition of inoculum for bioreactor $\mathrm{C}$ ) did not influence the final $\mathrm{pH}$ (as the digestates of all three set-ups recorded a $\mathrm{pH}$ of 5.9 at the end of $\mathrm{AD}$ ). Initiating $\mathrm{AD}$ at sub-atmospheric pressure appears not to have the same buffering effect on the $\mathrm{pH}$ as when $\mathrm{AD}$ is maintained at low pressures throughout the retention time, as reported by Jedrzejewska et al. (2010) and Jiang et al. (2005). Table 2 also reveals the microbial diversity and density of the feedstock and digestates of the bioreactors. Of all the fungi isolated from the feedstock, only Sporothrix schenkii and Cryptococcus albidus persisted in the digestate. Digestate from the bioreactor (C) initiated at atmospheric pressure with inoculum had the lowest microbial load due to a far reduced fungal population than the other two bioreactors, while the digestates from the bioreactor initiated at subatmospheric pressure (A) and that initiated at atmospheric pressure without inoculum (B) had similar total viable counts. Bacillus circulans, a facultative, which may have been responsible for scavenging traces of residual oxygen thus maintaining low oxygen potential in the bioreactors, were seen in equal measures in the digestates of all three bioreactors. The highest populations of methanogens were isolated from the digestate of the bioreactor (A) initiated at sub-atmospheric pressure, followed by the digestate of the bioreactor $(\mathrm{C})$ initiated at ambient atmospheric pressure with inoculum. This correlated with their respective biomethane yields as shown in Table 2. Results obtained here appear to disagree with claims made by Ofoefule et al. (2010) that biogas production is highly dependent on total viable counts; rather the results here suggest that biomethane (not biogas) production is dependent on specific methanogenic growth (and not total viable count). This assertion agrees with the findings of Nopharatana et al. (2007) and, Abubakar and Ismail (2012). Analyzing the populations of methanogens isolated from the different bioreactors relative to their biomethane yield suggests that Methanosarcina barkeri may have been largely responsible for most of the biomethane yield. The microbiological analysis also suggests that initiating AD with inoculum at ambient atmospheric pressure had a better sanitizing effect on the feedstock (with particular reference to eliminating the occurrence of Cryptococcus albidus and minimizing the 
explosion of fungal population in general) than initiating $\mathrm{AD}$ at ambient atmospheric pressure without inoculum or initiating $\mathrm{AD}$ at sub-atmospheric pressure.

Table 2. Microbial analysis, $\mathrm{pH}$ and volatile solids (VS) of feedstock and digestate

\begin{tabular}{|c|c|c|c|}
\hline & $\begin{array}{l}\left.\text { Prokaryotes (cfu } \mathrm{mL}^{-1}\right) \\
\text { (bacteria and methanogens) }\end{array}$ & Fungi (cfu mL $\mathrm{mL}^{-1}$ ) & $\begin{array}{l}\text { Total viable } \\
\text { count, TVC } \\
\left(\mathrm{cfu} \mathrm{mL} \mathrm{mL}^{-1}\right)\end{array}$ \\
\hline $\begin{array}{l}\text { Feedstock } \\
\mathrm{pH}, 7.9\left(30{ }^{\circ} \mathrm{C}\right) \\
\text { volatile solids (VS) of } \\
\text { total solids (TS), } 81.93 \%\end{array}$ & $\begin{array}{l}\text { Aeromonas salmonicida- } 1.30 \times 10^{6} \\
\text { Staphlylococcus aureus }-0.15 \times 10^{6} \\
\text { Total }=1.45 \times 10^{6}\end{array}$ & $\begin{array}{l}\text { Aspergillus flavus }-0.4 \times 10^{3} \\
\text { Fusarium culmorum }-2.0 \times 10^{3} \\
\text { Rhizopus nigricans }-5.0 \times 10^{3} \\
\text { Sporothrix schenkii }-9.0 \times 10^{3} \\
\text { Fusarium oxysporum }-10 \times 10^{3} \\
\text { Cryptococcus albidus }-2.5 \times 10^{6} \\
\text { Total }=2.53 \times 10^{6}\end{array}$ & $3.98 \times 10^{6}$ \\
\hline $\begin{array}{l}\text { Bioreactor (A) initiated at } \\
\text { sub-atmospheric pressure } \\
\mathrm{pH}, 5.9\left(29^{0} \mathrm{C}\right) \\
\text { volatile solids (VS) of } \\
\text { total solids (TS), } 40.33 \%\end{array}$ & $\begin{array}{l}\text { Bacillus circulans }-4 \times 10^{6} \\
\text { Methanobrevibacter ruminantum }-2.4 \times 10^{4} \\
\text { Methanobrevibacter arboriphilicus-2.8 } 2.10^{6} \\
\text { Methanosarcina barkeri }-2.8 \times 10^{6} \\
\text { Total }=9.62 \times 10^{6}\end{array}$ & $\begin{array}{l}\text { Cryptococcus albidus }-12.5 \times 10^{6} \\
\text { Candida krusei }-6 \times 10^{5} \\
\text { Candida albicans }-3 \times 10^{5} \\
\text { Sporothrix schenkii }-2 \times 10^{5} \\
\text { Total }=13.6 \times 10^{6}\end{array}$ & $23.22 \times 10^{6}$ \\
\hline $\begin{array}{l}\text { Bioreactor }(\mathrm{B}) \text { initiated at } \\
\text { atmospheric pressure } \\
\text { without inoculum } \\
\text { pH, } 5.9\left(29{ }^{0} \mathrm{C}\right) \\
\text { volatile solids (VS) of } \\
\text { total solids (TS), } 43.42 \%\end{array}$ & $\begin{array}{l}\text { Bacillus circulans }-4 \times 10^{6} \\
\text { Methanobrevibacter ruminantum }-0.4 \times 10^{6} \\
\text { Methanobrevibacter arboriphilicus }-2.2 \times 10^{6} \\
\text { Methanosarcina barkeri-0.8 } \times 10^{6}\end{array}$ & $\begin{array}{l}\text { Cryptococcus albidus }-13.5 \times 10^{6} \\
\text { Candida krusei }-2.7 \times 10^{5} \\
\text { Candida albicans }-2.8 \times 10^{5} \\
\text { Sporothrix schenkii-3.2 } \times 10^{5} \\
\text { Total }=14.37 \times 10^{6}\end{array}$ & $23.97 \times 10^{6}$ \\
\hline $\begin{array}{l}\text { Bioreactor (C) initiated at } \\
\text { atmospheric pressure } \\
\text { with } \\
\text { inoculum } \\
\text { pH, } 5.9\left(29^{\circ} \mathrm{C}\right) \\
\text { volatile solids (VS) of } \\
\text { total solids (TS), } 41.11 \%\end{array}$ & $\begin{array}{l}\text { Bacillus circulans }-4 \times 10^{6} \\
\text { Methanobrevibacter ruminantum-0.6 } \times 10^{6} \\
\text { Methanobrevibacter } \\
\text { arboriphilicus }-2.9 \times 10^{6} \\
\text { Methanosarcina barkeri- } 1.2 \times 10^{6}\end{array}$ & $\begin{array}{l}\text { Candida krusei-3.3 } \times 10^{6} \\
\text { Candida albicans }-8 \times 10^{5} \\
\text { Sporothrix schenkii-5 }-510^{5}\end{array}$ & $13.3 \times 10^{6}$ \\
\hline
\end{tabular}

\section{CONCLUSIONS}

Initiating $\mathrm{AD}$ at reduced atmospheric pressure $(-30 \mathrm{cmHg})$ and the addition of inoculum at ambient atmospheric pressure both increased biomethanation by $20.31 \%$ and $15.80 \%$, respectively. The slurries of the bioreactors initiated at sub-atmospheric pressure recorded the highest population of methanogens (corresponding to its high biomethane yield), while the bioreactors initiated at ambient atmospheric pressure with inoculum had a far reduced fungal population, thus the lowest total viable count. It should be noted here that from the results obtained in this study, biomethane yields (not biogas yields) were directly related to biodegradation (that is using VS reduction as a measure of biodegradation) and specific methanogens population. Hence biomethanation, as opposed to biogasification, appears to be a better index for estimating biodegradation and vice versa in an anaerobic digestion batch process. It should be noted also that initiating $\mathrm{AD}$ at the sub-atmospheric pressure of $30 \mathrm{cmHg}$ yielded the least amount of carbon dioxide. Thus initiating $\mathrm{AD}$ at sub-atmospheric pressure improved biodegradation and biomethanation, and reduced carbon dioxide (a greenhouse gas) production. Further experiments could be carried out, initiating $\mathrm{AD}$ at different sub-atmospheric pressures with a view to determining the optimum sub-atmospheric pressure for maximum biodegradation and biomethanation. Also, the parameters of initiating at sub-atmospheric pressure and the addition of inoculum could be 
combined in one experiment in order to study their synergistic effects on biodegradation and biomethanation.

\section{REFERENCES}

ABBASI, T.; TAUSEEF S. M.; ABBASI S. A. Biogas energy. New York: Springer, 2012. p. 11-23.

ABUBAKAR, B.; ISMAIL, N. Anaerobic digestion of cow dung for biogas production. ARPN Journal of Engineering and Applied Sciences, v. 7, n. 2, p. 169-172, 2012.

ADELEKAN, B. A. Potentials of selected tropical crops and manure as sources of biofuels. Chapter 1. In: Biogas. Rijeca: InTech Europe, 2012. Available in: http://www.intechopen.com/download/get/type/pdfs/id/31318. Access in: 13 Dec. 2013.

AL SEADI, T.; RUTZ, D.; PRASSL, H.; KOTTNER, M.; FINSTERWALDER, T.; VOLK, S.; JANSSEN, R. Biogas handbook. Esbjerg: University of South Denmark, 2008.

BOUGRIER, C.; CARRERE, H.; DELGENES, J. P. Solubilisation of waste activated sludge by ultrasonic treatment. Chemical Engineering, v. 106, p. 163, 2005. http://dx.doi.org/10.1016/j.cej.2004.11.013

DELGENES, J. P.; PENAUD, V.; MOLETTA, R. Pretreatments for Enhancement of Anaerobic Digestion of Solid Waste. Chapter 8. In: MATA-ALVAREZ, J. (Ed.). Biomethanization of the organic fraction of municipal solid wastes. London: IWA Publishing, 2003. p.7.

DEUBLEIN, D.; STEINHAUSER, A. Biogas from waste and renewable resources: an introduction. Weinheim: Wiley-VCH, 2008. p. 100-128.

DOMSCH, K. H.; GAMS, W.; ANDERSON, T. H. Compendium of soil fungi. London: Academic Press, 1980.

HENSYL, W. R.; FOLIFER, L. E. (Ed.). Manual of determinative bacteriology. Philadelphia: Lippincott Williams \& Wilkins, 1994.

JEDRZEJEWSKA, M.; KOZAK, K.; KRZEMIENIEWSKI, M. Effect of reduced pressure on anaerobic blood biodegradation. Polish Journal of Environmental Studies, v. 5, n. 1, p. 87-93, 2006.

JIANG, J.; DU, X.; NG, S.; ZHANG, C. Comparison of atmospheric pressure effects on the anaerobic digestion of municipal solid waste. Bioresource Technology, v. 101, n. 16, p. 6361-6367, 2010. http://dx.doi.org/10.1016/j.biortech.2010.03.068

JURCOANE, S.; RADOI-MATEI, F.; TOMA, R.; STELIAN, P.; VINTILOIU, A.; DIGUTA, C. Hydrolysis of agricultural biomass by combined pretreatment and enzymatic methods in order to Produce Biofuels. Zootehnie si Biotehnologii, v. 42, n. 1, p. 58-63, 2009.

INSAM, H.; WHITTLE, I.; GOBERNA, M. Microbes at work: from waste to resources. London: Springer, 2010. p. 40-47.

HURST, C. J.; CRAWFORD, R. L.; KNUDSEN, G. R.; MCINERNEY, M. J.; STETZENBACH, L. D. (Ed.). Manual of environmental microbiology. Washington, D.C.: ASM Press, 2002. p. 1008-1016. 
MIRAHMADI, K.; KABIR, M.; JEIHANIPOUR, A.; KARIMI, K.; TAHERZADEH, M. Alkaline pretreatment of spruce and birch to improve bio-ethanol and biogas production. BioResources, v. 5, n. 2, p. 928-938, 2010.

MONNET, F. An introduction to anaerobic digestion of organic wastes. Beauly: Remade, 2003. p. 1-24.

MUTHANGYA, M.; MSHANDETE, A.; KIVAISI, A. Two stage fungal pre-treatment for improved biogas production from sisal leaf decortication residues. International $\begin{array}{lllllll}\text { Journal of Molecular Science, v. 10, p. } & \text { 4805-4815, }\end{array}$ http://dx.doi.org/10.3390\%2Fijms10114805

OFOEFUlE, A. U.; UZODIMMA, E. O.; ANYANWU, C. N. Studies on the effect of anaerobic digestion on the microbial flora of animal waste 2: digestion and modeling of process parameters. Trends in Applied Sciences Research, v. 5, p. 39-47, 2010. http://dx.doi.org/10.3923/tasr.2010.39.47

OJOLO, S. J.; OKE, S. A.; ANIMASAHUN, K.; ADESUYI, B. K. Utilization of poultry, cow, and kitchen waste for biogas production: a comparative analysis. Iran Journal Environmental Health Science Engineering, v. 4, n. 4, p. 223-228, 2007.

NDA-UMAR, U. I.; UZOWURU, M. G. Anaerobic co-digestion of fruit waste and abattoir effluent. Journal of Biological Science and Bioconservation, v. 3, n. 1, p. 26-34, 2011.

NOPHARATANA, A.; PULLAMMANAPPALliL, P. C.; CLARKE, W. P. Kinetic and Dynamic Modeling of Batch Anaerobic Digestion of Municipal Solid Waste in a Stirred Reactor. Waste Management, v. 27, p. 595-603, 2007. http://dx.doi.org/10.1016/j .wasman.2006.04.010

PALMOWSKI, L. M; MULLER, J .A. Influence of the Size Reduction of Organic Waste on their Anaerobic Digestion. Water Science Technology, v. 41, n. 3, p. 155-162, 2000.

PAKARINEN, A.; MAIJALA, P.; JAAKKOLA, S.; STODDARD, F.; KYMALAINEN, M.; VIIKARI, L. Evaluation of preservation methods for improving biogas production and enzymatic conversion yields of annual crops. Biotechnology for Biofuels, v. 4, n. 20, p. $1-13,2011$

PILLAI, S. P. R. A comprehensive laboratory manual for environmental science and engineering. New Delhi: New Age International Publishers, 2009. p. 7-11.

SCHNURER, A.; JARVIS, A. Microbiological handbook for biogas plants. Malmö: Avfall Sverige, 2010. p. 8-22.

TIEHM, A.; NICKEL, K.; ZELLHORN, M.; NEIS, U. Ultrasonic waste activated sludge disintegration for improving anaerobic stabilization. Water Research, v. 35, p. 20032009, 2001. http://dx.doi.org/10.1016/S0043-1354(00)00468-1

VINDIS, P.; MURSEC, B.; JANZEKOVIC, M.; CUS, F. The impact of mesophilic and thermophilic anaerobic digestion on biogas production. Journal of Architecture Material and Manufacturing Engineering, v. 36, n. 2, 2009.

WISTREICH, G. A. Microbiology laboratory. Fundamentals and Applications. $2^{\text {nd }}$ Ed. New Jersey: Pearson Education, 2003. p. 139-256. 